\title{
Agnieszka Jakubowska
}

Uniwersytet im. Adama Mickiewicza w Poznaniu

\section{Język wypowiedzi publicznych Jarosława Kaczyńskiego w latach 2007-2010}

\section{WPROWADZENIE}

TarosŁaW Kaczyśski od wielu lat jest ważnym, a od sporego czasu również wiodącym aktorem na polskiej scenie politycznej. W 1976 r. rozpoczął współpracę z Komitetem Obrony Robotników. Od 1979 r. należał do redakcji niezależnego miesięcznika „Głos”. W 1980 r. został członkiem „Solidarności”, kierował w jej ramach sekcją prawną. W stanie wojennym zajmował się dystrybucją wydawnictw podziemnych. W 1982 r. nawiązał współpracę z Komitetem Helsińskim, natomiast rok później z niejawnymi władzami NSZZ „S”. W trakcie strajków w 1988 r. doradzał pracownikom ze Stoczni Gdańskiej im. Lenina. Brał udział w obradach Okrągłego Stołu, w lipcu i sierpniu 1989 r. reprezentował NSZZ „S” w zespole negocjacyjnym pracującym nad powołaniem koalicyjnego rządu. W latach 1990-1991 był ministrem stanu, Szefem Kancelarii Prezydenta Lecha Wałęsy. W roku 1990 powołał Porozumienie Centrum, której to partii prezesem był do 1998 r. W 2001 r. znalazł się wśród pomysłodawców i założycieli nowej formacji politycznej: Prawa i Sprawiedliwości. W 2003 r. po raz pierwszy został wybrany na Prezesa PiS. We wrześniu 2005 r. Prawo i Sprawiedliwość pod jego przewodnictwem wygrało wybory parlamentarne. 10 lipca 2006 r. został desygnowany na stanowisko Prezesa Rady Ministrów przez Prezydenta RP, Lecha Kaczyńskiego¹. Rządem kierował do 16 listopada 2007 r. Był senatorem I kadencji, posłem I, III, IV i V kadencji ${ }^{2}$. W 2005 r. został „Człowiekiem Roku” w rankingu tygodnika „Wprost”.

${ }^{1} 10$ lipca 2006 r. Prezes Rady Ministrów, Kazimierz Marcinkiewicz podał się do dymisji. Tego samego dnia Prezydent RP Lech Kaczyński desygnował na premiera Jarosława Kaczyńskiego, który wraz ze swoim gabinetem został zaprzysiężony 14 lipca 2006 r. Nowy premier otrzymał wotum zaufania od Sejmu 19 lipca 2006 r.

${ }^{2}$ Sejm RP, notka biograficzna Jarosława Kaczyńskiego, http://sejm.gov.pl/poslowie/posel6/137.htm, 10.04.2011 r., Jarosław Kaczyński, notka biograficzna Jarosława Kaczyńskiego, http://www.jaroslawkaczyn ski.com.pl/, 10.04.2011 r.

${ }^{3}$ A. Blinkiewicz, Rok Jarosława - Człowiek Roku 2005, „Wprost”, http://www. 
Życiorys polityczny J. Kaczyńskiego jest naprzemiennym pasmem działalności opozycyjnej i sprawowania władzy. Czasowo działalność opozycyjna znacząco przeważa jednak nad rządzeniem, choć oczywiście inną jest opozycyjność w okresie PRL-u, inną natomiast w III RP. Pierwsza była opozycyjnością dysydenta, sprzeciwiającego się ustrojowi monopartyjnemu, walczącego w obronie wolności i demokracji. Druga to opozycyjność parlamentarzysty w ustroju demokratycznym, a obecnie lidera największej partii opozycyjnej, która występuje przeciwko polityce i działalności rządu, przedstawia alternatywne rozwiązania polityczne i ekonomiczne oraz dąży do przejęcia lub zmiany władzy w państwie ${ }^{4}$.

Artykuł dotyczy charakterystyki publicznych wypowiedzi J. Kaczyńskiego jako opozycjonisty „dwukrotnego” i antyustrojowego wobec PRL i III RP. Materiał badawczy zaczerpnięto z lat 2007-2010, a dokładniej z okresu od 16 listopada 2007 r. (zaprzysiężenie rządu PO-PSL) do 10 kwietnia 2010 r. (katastrofa prezydenckiego samolotu TU-154 w Smoleńsku). Założono, że tragedia w Rosji zmieniła klimat polityczny w Polsce, a język i stosunki polityczne uległy redefinicji. $\mathrm{Z}$ tego względu uznano, że próba włączenia do badania wypowiedzi wygłaszanych przez J. Kaczyńskiego po katastrofie mogłaby okazać się nie tylko trudna, lecz również metodologicznie wadliwa.

Celem badania jest odpowiedź na pytanie, jakie były cechy charakterystyczne języka wypowiedzi publicznych J. Kaczyńskiego w latach 2007-2010, a także do jakiego stopnia język ten był językiem opozycjonisty aprobującego system polityczny. Innymi słowy, artykuł ma odpowiedzieć, czy w badanym okresie w wypowiedziach J. Kaczyńskiego przeważały cechy języka opozycji systemowej, czy raczej cechy języka opozycji antysystemowej.

\section{JĘZYK POLITYKI}

PRZYSTĘPUJĄC DO ANALIzY, należy wyjaśnić pojęcia: „język”, „język polityki” oraz „język opozycji”, a także „język opozycji systemowej” i „język

wprost.pl/ar/85838/Rok-Jaroslawa-Czlowiek-Roku-2005/, 10.04.2011 r.

${ }_{4}^{4}$ Oczywiście, należy przyjąć, że J. Kaczyński jest świadom tej różnicy, co poświadczają liczne jego wypowiedzi. Jego zdaniem, nie da się oddzielić recenzowania rządu od prób forsowania własnych inicjatyw: „Recenzowanie jest oczywistą funkcją opozycji. Ale trzeba też przedstawiać propozycje własne. Oczywiście wtedy, kiedy jest cień szansy na ich realizację. Tam gdzie jej nie ma, można je promować w mediach. Jednak zbyt wielka liczba inicjatyw ustawodawczych Sejmowi nie służy" (5.02.2002 r.), A. Sarzyńska, Rozmowa z Jarosławem Kaczyńskim, http://www.pis.org.pl/article.php?id=2182, 29.06.2010 r. 
opozycji antysystemowej”. Ludzie porozumiewają się ze sobą i między sobą dzięki wyartykułowanym przez siebie myślom. Owe przemyślenia trafiają do odbiorców pod postacią znaków mówionych i pisanych. System tych znaków, obejmujący także reguły ich tworzenia i łączenia, użytkowany przez określoną grupę ludzi, nazywa się „językiem”. Należy zatem pamiętać, że „język” ma charakter społeczny - jak zauważył Emile Benveniste, „rodzi się w tym samym procesie, co społeczeństwo"6.

„Język polityki” jest równie różnorodny, jak liczne są sprawy, których dotyczy polityka. Konsekwencją tego jest trudność wydzielenia przedmiotowej domeny tego języka, tj. zakresu charakterystycznych tematów, przy omawianiu których nadawcy posługują się „językiem polityki”. W związku z tym łatwiej zakreślić jego granice przy pomocy definicji podmiotowej, opierającej się na prostym założeniu, że jest to język, którym posługują się ludzie mówiący lub piszący o polityce, a więc politycy, ludzie z nimi związani, czyli doradcy, rzecznicy prasowi, specjaliści z zakresu socjotechniki, propagandy, reklamy itp., ale także np. politolodzy, dziennikarze - często wyspecjalizowani w pisaniu o polityce7.

Stanowisko takie godzi się z koncepcją Stanisława Dubisza, który założył, że ,język polityki” lokuje się pomiędzy polszczyzną ogólną, a jej stylami funkcjonalnymi. Stwierdził również, że znaczenie terminu ma dwa aspekty. Po pierwsze, przez „język polityki” winno się rozumieć słownictwo i frazeologię, które odnoszą się do działalności politycznej; jest on wtedy jednym z wariantów przedmiotowych polszczyzny. Po drugie, można określać tym terminem wypowiedzi ludzi związanych z życiem politycznym, które tworzą łącznie wewnętrznie zróżnicowany i oparty na różnych odmianach polszczyzny dyskurs polityczny ${ }^{8}$.

Zdaniem Zbigniewa Bloka, dodatkowym utrudnieniem w definiowaniu ,języka polityki” jest występowanie dużych różnic językowych, które zależą od takich czynników jak: pochodzenie, zamieszkanie, zajmowana pozycja w strukturze społecznej, poziom kultury osobistej,

${ }^{5}$ Z. Blok, Teoria polityki, Poznań 1999, s. 25.

${ }^{6}$ E. Benveniste, Struktura języka i struktura społeczeństwa, [w:] Język i społeczeństwo, red. M. Głowiński, Warszawa 1980, s. 32.

7 B. Walczak, Co to jest język polityki, [w:] Język i kultura t. XI: Język polityki i wspótczesna kultura polityczna, red. J. Anusiewicz, B. Siciński, Wrocław 1994, s. 1520.

${ }^{8}$ P. Worobiec, Leksykalny kod polityczny-językowy: Obraz wroga, [w]: Język komunikacja, red. K. Kleszcza, M. Krzempek, Opole 2008, s. 22-23. 
etc. ${ }^{9}$ Jednak jak stwierdził Jerzy Bralczyk, istnieje przeświadczenie, że „język polityki” jest osobną odmianą „języka”, a także, że politycy mówią inaczej, zwłaszcza gdy mówią publicznie. Nie ma zatem dziś jednego „języka polityki”, są różne jego odmiany. Dlatego też każdy polityk może mówić i mówi na swój sposób, nie obawiając się co do zasady, że za dowolność językową spotka go sankcja prawna, moralna czy obyczajowa ${ }^{10}$. Jest to znacząca różnica między współczesnością a czasami, kiedy mieliśmy do czynienia z jednorodną perswazją - propagandą polityczną. Wtedy to ludzie wypowiadający się oficjalnie dostosowywali swe wypowiedzi do wzorców i szablonów mówienia politycznego i ideologicznego, określanych mianem „nowomowy” ${ }^{11}$.

Należy zgodzić się z tezą J. Bralczyka, że każdy polityk mówi w sposób jedyny i indywidualny. Jednak, jak słusznie zauważył ten autor, mimo indywidualizacji „języka polityki”, można usiłować uchwycić katalog pewnych charakterystycznych znamion, jakie cechują wypowiedzi polityczne. Znamionami tymi są: duże nasycenie nazwami generalnymi i abstrakcyjnymi, normatywny charakter terminów, narzucanie ocen, ich ogłaszanie i uzasadnianie, narzucanie wymagań, roszczeń, formułowanie nakazów, zakazów, rygoryzm a nawet represywność, silny ładunek emocji, wysoki poziom stronniczości i tendencyjności, równocześnie wieloznaczności, obciążonej zręcznością pragmatyczną i hipokryzją ${ }^{12}$. Ponadto, zdaniem Mirosława Karwata, ,język polityki cechuje się swoistym natręctwem”. Wyraża się ono w sporym natęże-

${ }_{9}^{9}$ Z. Blok, Teoria..., op. cit., s. 33 .

${ }^{10} \mathrm{~J}$. Bralczyk, Perswazja $w$ tekstach politycznych. Wprowadzenie do dyskusji, [w]: Język perswazji publicznej, red. K. Mosiołek-Kłosińska, T. Zgółka, Poznań 2003, s. 105.

${ }^{11}$ Należy mieć świadomość, że termin ten nie spełnia wymogów, jakie zwykle nakłada się na terminy stricte naukowe. Określenie to pochodzi z ang. newspeak i pierwotnie oznaczało język opisany w totalitarnym państwie z powieści Rok 1984 Georga Orwella. Nowomowa była stosowana w PRL-u. Wypowiedzi władzy cechowała wówczas magiczność, rytualność, schematyczność, i „szablonizacja”. W konsekwencji komunikacja władzy z obywatelem miała charakter pozorny. Była fikcją tworzoną podczas wystąpień na plenach i zebraniach, wyrażającą się w hasłach. Badając „komunistyczną nowomowę” „Zwracano uwagę na wartościujący charakter niby-opisowych sądów, na deklaracyjną i kontrolną funkcję tekstów, na ich specyficznie sformalizowaną dyrektywność, także na przewagi ideologii nad sensem, nad wiernością ustabilizowanemu leksykonowi, nad regułami frazeologii i składni”. J. Bralczyk, Język polityki i polityków, [w]: O zagrożeniach i bogactwie polszczyzny, red. J. Miodek, Wrocław 1996, s. 122. Por. M. Głowiński, Nowomowa i ciągi dalsze. Szkice dawne i nowe, Kraków 2009; W. Pisarek, O mediacji i języku, Kraków 2007, s. 356-368; A. Bihr, Nowomowa neoliberalna, Warszawa 2008, s. 14-18.

${ }^{12}$ M. Karwat, Perswazja $w$ tekstach politycznych-spojrzenie politologa, [w]: Język perswazji publicznej, red. K. Mosiołek-Kłosińska, T. Zgółka, Poznań 2003, s. 112. 
niu nacisku, monotonnej wytrwałości oddziaływań, w których politycy pokazują jak bardzo zależy im, by inni (wyborcy, zwolennicy) ulegli ich namowom, pokusom, przestrogom. M. Karwat zwrócił również uwagę na to, że oceny, roszczenia i nakazy/zakazy często przewyższają obraz zjawisk, a ich stopień jest tak wysoki, że można pokusić się o stwierdzenie, że dla aktorów sceny politycznej najmniej ważny jest przekaz informacji. Informacje są przekazywane, ale zawsze odpowiednio zabarwione i zawoalowane: intencjami, emocjami, komentarzami, które politycy starają się narzucić innym. Dodatkowo przemycane są oceny, nastawienia, oferty, apele czy groźby, a fakty są selekcjonowane i preparowane ${ }^{13}$. Wszystkie zabiegi: ogólniki, banały, frazesy, mają służyć temu, by nie urazić odbiorcy, nie powiedzieć za dużo, poszerzyć zasięg oddziaływań i jednocześnie uniknąć zobowiązań i odpowiedzialności. W rezultacie, jak zauważył M. Karwat, obecny „język polityki” jest wieloznaczny i wielofunkcyjny ${ }^{14}$.

Założono, że nie ma jednej, całościowej definicji ,języka opozycji”, dlatego, na potrzeby artykułu przyjęto, że jest on wersją języka, wyrosłą z języka sprzeciwu (wobec władzy, rządu, systemu politycznego, społecznego, gospodarczego, etc.), posługującą się głównie emocjonalnymi środkami wyrazu ${ }^{15}$. Można stwierdzić, że w PRL-u, ,język opozycji” był jednocześnie ,językiem opozycji antysystemowej”, gdyż był przykładem oporu społecznego wobec zideologizowanej polszczyzny oficjalnej. Cechował go wysoki stopień emocjonalności, nazywał rzeczywistość wprost, demaskował zakłamanie i nieudolność rządzących (antytotalitarny). Wyrósł z języka mówionego, stosowanego jako jedyny sposób walki z ustrojem socjalistycznym. Był wyrazem autoekspresji, zrodzonej pod wpływem gniewu wywołanego przemocą stosowaną przez wroga (rząd, aparat partyjny, podległe im instytucje). Ponadto spełniał on funkcję integracyjną, przedstawiając dychotomiczny obraz świata za pomocą opozycji zaimków („my” i „oni”). Przedstawiał także jedność celów i potrzebę wspólnoty poprzez używanie takich czasowników, jak: „musimy”, „mamy”, „powinniśmy”16.

„Język opozycji systemowej” jest legalnym językiem opozycji, któ-

${ }^{13}$ Ibidem, s. 113-114.

${ }_{14}$ Trafne jest porównanie M. Karwata: wypowiedzi polityczne „skonstruowane są podobnie jak karabin wielostrzałowy: jednym naciśnięciem spustu strzelamy do kilku obiektów naraz i osiągamy kilka efektów".

${ }^{15}$ I. Kamińska-Szmaj, Stowa na wolności. Język polityki po 1989 roku, wypowiedzi, dowcip polityczny, słownik inwektyw, Wrocław 2001, s. 9.

${ }^{16}$ Ibidem, s. 28-29. 
ry nie kwestionuje obecnego systemu, a jedynie sprzeciwia się działaniom rządu i innych podmiotów życia politycznego; nie kontestuje ich legalności. Służy m.in. ukazaniu: wad (systemu, rządzenia, postępowania), istniejących problemów (politycznych, gospodarczych, społecznych, etc.), zwróceniu uwagi na negatywne, niepokojące zjawiska. Można dopuścić się stwierdzenia, że w Polsce, po 1989 r. ,język opozycji antysystemowej” został zastąpiony przez ,język opozycji systemowej”, którego cechami charakterystycznymi, są: lekkość, swoboda, prostota (język potoczny, codzienny), pochodzący z różnych odmian środowiskowych ${ }^{17}$.

\section{JĘZYK JarosłaWa KaCZYŃSKIEGo W LATACH 2007-2010}

JĘZYKIEM MOŻNA OPEROWAĆ zarówno ofensywnie, jak i defensywnie. Im większy zasób słów, środków stylistycznych i retorycznych, jakimi dysponuje użytkownik języka, tym większe spektrum działania, silniejszy atak czy opór i bardziej skuteczna walka językowa. J. Kaczyński w latach 2007-2010, wykorzystując swoje doświadczenie polityczne, posługiwał się językiem z wielką precyzją. Niekiedy subtelnie, innym razem z impetem wykorzystywał narzędzia językowe, by osiągać cele polityczne, stosując przy tym świadomie lub intuicyjnie różnorakie środki i techniki.

Jedną z głównych cech ,języka polityki”, tym bardziej „języka opozycyjnego" jest używanie haseł populistycznych w celu zjednania sobie społeczeństwa i uzyskania jego poparcia. Wypowiedzi takie odznaczają się znacznym stopniem zdecydowania, stanowczości, operuje się w nich pojęciami nieostrymi, identyfikowanymi życzeniowo ${ }^{18}$. J. Kaczyński regularnie posługując się takimi hasłami, prezentował się jako obrońca i strażnik praw obywateli, które to prawa ogranicza jakoby, zawłaszcza i likwiduje „zły” rząd. Polityk chętnie używał takich słów jak: „demokracja”, „wolność”, „sprawiedliwość”, „równość”, „standardy”, „solidaryzm”, „społeczeństwo obywatelskie”19. Pojęcia te funkcjonowały w jego wypowiedziach jako „słowa - klucze”. Okre-

${ }^{17}$ Ibidem, S. 59.

${ }^{18} \mathrm{~J}$. Bralczyk, Ojęzyku..., op. cit., s. 89.

19 Np. „W wyjątkowo ostry sposób naruszała zasadę społecznej sprawiedliwości i przyzwoitości społecznej” (15.12.2008 r.), Prezes PiS: ustawa o „pomostówkach” to bubel prawny i spoteczny, http://www.pis.org. pl/article.php?id=14022, 11.05.2010 r.; „To nie jest żaden kompromis, tu nie chodzi o wolę tej czy innej partii, chodzi o standardy" (6.01.2010 r.), Szef PiS: nie pomożemy w upadku hazardowej komisji śledczej, http://www.pis.org.pl/article.php?id=16556, 11.05.2010 r. 
ślały skrótowo program polityczny PiS i cele tego programu. Służyły „autoidentyfikacji podmiotów politycznych”, pełniąc rolę niejako „znaków rozpoznawczych”, ,a także działaniom deklaracyjnym przez autonomizację oraz zabieg świadomego i nawet manifestacyjnie nowego nazywania rzeczy".

J. Kaczyński bardzo umiejętnie posługiwał się toposami retorycznymi ${ }^{20}$, przedstawiając i negując obecny ustrój jako swoistą kontynuację PRL-u. Podkreślał swą opozycyjność wobec aktualnych elit rządzących, przypominał o idei, zgodnie z którą III RP winna zostać zastąpiona przez IV RP (np. „To jest IV Rzeczpospolita - to Polska sukcesu")21. Przeciwstawiając dwie Rzeczypospolite, wykorzystywał symbolikę numeracyjną, w której „IV” oznaczała nową, lepszą jakość. Odwoływał się również do metaforyki „końca czegoś”, a także „początku”, „rozpoczęcia”, „odbudowy”, „ocalenia”, „porządku”, „oczyszczenia”. Korzystając z nich, usiłował wprowadzać pozytywny nastrój i stwarzać poczucie bezpieczeństwa, jak również przekonywać, że gotów jest do odpowiednich działań, mających na celu poprawę obecnej sytuacji. Deklaracje tego typu stawały się niemal obietnicą wprowadzenia wciąż oczekiwanego jakoby przez odbiorców (społeczeństwo) porządku wolnego od układu czy zmowy elit.

W latach 2007-2010 J. Kaczyński, podobnie jak w czasach rządów SLD, sugerował wielokrotnie, że ugrupowania konkurujące z PiS, w tym tworzące koalicję rządzącą są duchowymi spadkobiercami PRL$-\mathrm{u}^{22}$. W jego opinii, „Polska Anno Domini 2008 to zmutowane głęboko państwo komunistyczne z aparatem, który nigdy nie został zlikwidowany” ${ }^{23}$. Stwierdził też: „Ale już w czasie kampanii wyborczej 2005

${ }^{20}$ Retorykę pojmuje się jako sztukę mówienia: umiejętnego, dobrego i rzetelnego, a przede wszystkim skutecznego, w celu przekonywania słuchaczy, czyli przekazywania treści perswazyjnych (krasomówstwo).

${ }^{21}$ Wypowiedź z 31.01.2008 r., II Kongres Prawa i Sprawiedliwości w Krakowie, http://www.pis.org. pl/article. php?id=14332, 11.05.2010 r.

${ }^{22}$ W czasie rządów SLD, J. Kaczyński często formułował sądy takie, jak: „Mamy dzisiaj wielką siłę formacji lewicowej i to formacji z najgorszej tradycji - tradycji pezetpeerowskiej, tradycji uzależnienia od obcego mocarstwa" (26.08.2001 r.), Jarostaw Kaczyński: prawica formacją przyszłości, http://www.pis.org.pl/ article.php?id=1225, 11.05.2010 r.; „Ponieważ my uważamy, że odsunięcie SLD od władzy jest naszym zadaniem, można powiedzieć, patriotycznym” (14.10.2002 r.), Jarosław Kaczyński: Polska wymaga oczyszczenia i skończenia z układami, http://www.pis.org.pl/article. php?id=1574, data odczytu: 10.05 .2010 r.; „SLD prowadzi politykę renomenklaturyzacji Polski” (6.11.2002 r.), Jarosław Kaczyński: SLD prowadzi politykę renomenklaturyzacji Polski, http://www.pis.org.pl/article.php?id=1474, 17.10.2010 r.

${ }^{23}$ Wypowiedź z 6.05.2008 r., Jarosław Kaczyński w Radomiu o naprawie Polski, 
roku było widać, że (PO - przyp. A. J.) rezygnuje z tego kamuflażu, bo jak się okazało, był to tylko kamuflaż, i po prostu staje się nową partią chroniącą establishment stworzony przez III Rzeczypospolitą. Przedtem taką partią, główną taką partią było SLD, a SLD upadło i w to miejsce weszła Platforma Obywatelska"24. Oceniając politycznych konkurentów, prezes Prawa i Sprawiedliwości nie stronił od słów ostrych, niekiedy obraźliwych, a nawet wulgarnych. Ton jego ocen był zdecydowany, często oskarżycielski, nierzadko nasycony nieufnością i podejrzliwościąa 5 . Używał stanowczych stwierdzeń, które wypowiadał silnie emocjonalnie, szczególnie przy okazji dyskutowania projektów ustaw czy uchwał, w debatach nad nimi bądź nad stwierdzonymi czy domniemanymi aferami. Dodatkowo stosował mocne rzeczowniki, łączył je z przysłówkami i stopniował, by pokazać błędy rządu (np. „Skandal i to jest arcyskandal”)26. W jego wypowiedziach pojawiały się też typowe określenia pejoratywne, np. „To samo dotyczy ubowców"(8.05.2008 r.) ${ }^{27}$. Nie stronił od wypowiadania sądów kategorycznych, niepodlegających jakoby dyskusji (np. „Jak boi się, to jest

http://www.pis.org. pl/article.php?id=12464, 11.05.2010 r.

${ }_{24}$ Wypowiedź z 4.09.2008 r., Rozmowa M. Mądrzejewskiego z Jarosławem Kaczyńskim w „Sygnałach Dnia”, http://www.pis.org.pl/article.php?id=13250, 11.05.2010 r.

${ }^{25} \mathrm{~J}$. Kaczyński o działaniach podmiotów politycznych, innych niż jego partia, nieraz wypowiadał się jako o przejawach spisku (spiskowe widzenie świata). Sam stawiał się w pozycji tego, który ten spisek miał wykryć, ujawnić, ochronić przed nim społeczeństwo. M. Głowiński, Nowomowa i ciągi dalsze. Szkice dawne i nowe, Kraków 2009, S. 211-223.

${ }^{26}$ Wypowiedź z 19.09.2008 r., Rozmowa J. Karnowskiego z Jarostawem Kaczyńskim w „Sygnałach Dnia”, http://www.pis.org.pl/article.php?id=13354, 11.05.2010 r.

${ }^{27}$ Rozmowa J. Karnowskiego z Jarosławem Kaczyńskim w „Sygnałach Dnia”, http://www.pis.org.pl/ article.php?id=12489, 11.05.2010 r. Formant -owiec, -ista, - ak, -izm, -izna, ma konotację negatywną, uproszczoną, jednoznacznie się kojarzącą, nawiązującą do niechlubnej przeszłości, ma na celu zdyskredytowanie osób czy rzeczywistości politycznej. Za ich pomocą tworzone są neologizmy czy przymiotniki, używane jako obraźliwe epitety; np. „Jest to niezmiernie destruktywne dla Polski, pokazując prawdziwy charakter PO (...), która prowadzi kraj ku putinadzie” (7.02.2008 r.), Wywiad P. Jakuckiego z Jarosławem Kaczyńskim na tamach „Naszej Polski”, http://www.pis. org.pl/article.php?id=11543, 11.05.2010 r.; „Panie redaktorze, ja tuskologią się nie będę zajmował, nie będę komentował cech charakteru premiera (...)" (5.07.2008 r.), Rozmowa M. Mądrzejewskiego z Jarosławem Kaczyńskim w „Sygnałach Dnia”, http://www. pis.org.pl/article.php?id=12962, 11.05.2010 r.; „Jeszcze Grzegorz Schetyna, działacz NSZ, z ładną przeszłością(...) niech już pozostanie, ale otoczenie, wszyscy ludzie z AWS-u, z tomaszewszczyzny(...)” (23.11.2007 r.), Jarosław Kaczyński: chcemy być życzliwi, ale opozycja musi być krytyczna, http://www.pis.org.pl/article.php?id=10922, 11.05.2010 r. 
winny") ${ }^{28}$. Często stosował wyrażanie sugerujące, tak, jakby jego sposób widzenia świata był wyjątkowo trafny, a nawet jedynie słuszny.

Częstym zabiegiem stosowanym przez J. Kaczyńskiego w latach 2007-2010 była rematyzacja ${ }^{29}$, czyli językowe uwypuklanie treści, na których przekazaniu najbardziej zależy nadawcy. Najczęściej efekt uwypuklenia uzyskuje się poprzez uporczywe powracanie do sądów najistotniejszych (ang. thematic persistence) ${ }^{30}$. W wypowiedziach J. Kaczyńskiego odnaleziono wiele rematów, należały do nich: „układ”, „establishment”, „propaganda”, „oligarchia”, „elita”, „grupa”, „spisek”, „socjotechnika”, „PRL”, „postkomuna”, „postkomuniści”, „lobby”, „front”, „klientyzm (klientelizm)”, „środowisko”. Lider PiS często stosował powtórzenia, szczególnie z użyciem przytoczonych rematów, co ułatwiało odbiór jego oświadczeń (zdania proste, mnogość czasowników, rzeczowników). Dzięki powtórzeniom wypowiedzi wypadały bardziej dynamicznie, ciekawiej ${ }^{31}$.

\section{JAROSŁAW KACZYŃSKI JAKO SOCJOTECHNIK?}

ANALIZA wyPOWIEDZI J. KACZYŃSKIEGO z lat 2007-2010 prowadzi do wniosku, że potwierdzają one prawdziwość prawa Zipfa, że „wyraz użyty raz, zwłaszcza znaczący, nacechowany, ma (...) dużą szansę pojawienia się w tym samym tekście, najczęściej w bliskim sąsiedztwie" ${ }^{2}$. Co więcej zdarzało się tak, że dane słowo pojawiało się w języku J. Kaczyńskiego i było przez niego używane przez jakiś czas, szczególnie, gdy dotyczyło ważnej sytuacji, zdarzenia, ustawy. Np. słowo „landyzacja” (neologizm

${ }^{28}$ Wypowiedź z 5.10.2009 r., Jarosław Kaczyński: usunięcie Kamińskiego jak przyznanie się do winy, http://www.pis.org.pl/article.php?id=15939, 11. 05. $2010 \mathrm{r}$.

${ }_{29}$ Remat - to coś nowego, dodanego, co ma zmienić opinie odbiorcy, ma zwrócić jego uwagę lub zostać najlepiej zapamiętane.

${ }^{30} \mathrm{~J}$. Bralczyk, O języku..., op. cit., s. 59.

${ }^{31}$ Niemniej należy pamiętać, że przesadnie częste powtarzanie danych słów czy fraz może wbrew intencji nadawcy prowadzić do zanikania sensu wypowiedzi; słuchacz gubi się w odbiorze, mowa staje się tautologiczna. Determinacja w używaniu kilku podstawowych pojęć, przesada w tej praktyce może wzbudzać w odbiorcy przeświadczenie, że nadawca cierpi na manię, że nie posiada bogatego zasobu słownictwa czy wreszcie, że brakuje mu smaku językowego. Powtarzanie sądów jak mantry może niepokoić, stwarza bowiem wrażenie jakby stosujący ten zabieg nigdy nie zmieniał zdania; np. „Panie redaktorze, to jest tak, że są takie decyzje, które można traktować jako błąd, bo można było podjąć decyzję inną, i są takie decyzje, które mogły być niefortunne, ale których trudno traktować jako błąd, bo trudno było podjąć inną decyzję. I to właśnie była taka decyzja" (29.05.2008 r.); Rozmowa J. Karnowskiego z Jarostawem Kaczyńskim $w$ „Sygnałach Dnia”, http://www.pis.org. pl/article.php?id=12641, 11.05.2010 r.

${ }^{32} \mathrm{~J}$. Bralczyk, O języku polskiej polityki lat osiemdziesiątych i dziewięćdziesiątych, Warszawa 2003, s. 263. 
J. Kaczyńskiego) pojawiło się we wrześniu 2009 r., gdy PO chciała zmienić ustawę dotyczącą samorządów. W tym czasie lider opozycji używa też słowa „land”33. J. Kaczyński twierdził zatem, że „Największym zagrożeniem jest landyzacja Polski, czyli przekazanie większych kompetencji samorządom, zredukowanie kompetencji wojewody, oddzielenie funkcji prokuratora generalnego i ministra sprawiedliwości. $\mathrm{Z}$ jaką racjonalnością mamy tutaj do czynienia? To jest racjonalność władzy establishmentu. Ta grupa została straszliwie przestraszona naszymi rządami. Obecna władza wykonuje zobowiązania wobec tej grupy. Ci którzy zamordowali Olewnika, w takiej strukturze mogliby się czuć bezpiecznie" (26.05.08) ${ }^{34}$.

W powyższym przykładzie można odnaleźć wszystkie omówione dotychczas cechy języka, jakim J. Kaczyński posługiwał się w latach 2007-2010. W wypowiedzi tej zastosowano zatem takie techniki jak populizm, a także odwołanie do strachu, czyli przestrzeganie przed czymś bardzo złym i niebezpiecznym, czymś co próbował wprowadzić rząd. Lider PiS podkreślił nieracjonalność PO i zarazem wykazywał dlaczego i w czyim interesie rządzący podjęli krytykowane działania. W wypowiedzi użyto również ramatyzacji: „establishment”, „grupa”, a ponadto aluzję: „Ci którzy zamordowali Olewnika”.

Kumulacja zabiegów retorycznych i stylistycznych w wypowiedziach J. Kaczyńskiego nie jest zjawiskiem rzadkim i przypadkowym. Odpowiada ona charakterowi tego polityka, jego konfrontacyjnemu czy bezkompromisowemu sposobowi bycia. Słowa, a w szczególności rematy, J. Kaczyński umieszczał w swoistych kontekstach, łącząc je regularnie z określonymi emocjami, dzięki czemu nadawał im odmienną od utartej, często negatywną konotację. W rezultacie rematy

33 „Wtedy rząd Tuska dokonał bifinlandyzacji Polski, wobec Niemiec i wobec Rosji” (11.09.2009 r.), Rozmowa M. Graczyka z Jarosławem Kaczyńskim w „Dzienniku”, http://www.pis.org.pl/article.php?id=15787, 2.11.2010 r., „To była ta landyzacja Polski, ta strefa szczególnej współpracy z Niemcami na Zachodzie, z Rosjanami na Wschodzie. Tam były dyskretnie przedstawiane, ale bardzo zdecydowanie, także mnie to przedstawiano, dokładnie ówczesny premier Bielecki mnie to przedstawiał - plany likwidacji Wojska Polskiego, czyli Polska, która jest bez armii. No, proszę zwrócić uwagę - Polska zlandyzowana, tutaj strefa współpracy z Niemcami, tutaj z Rosją, Polska nie ma armii. Czyli krótko mówiąc co? Kondominium niemiecko-rosyjskie, strefa zamieszkiwania Polaków, a nie żadne państwo" (16.09.2009 r.); Rozmowa H. Szrubarza z Jarostawem Kaczyńskim w „Sygnałach Dnia”, http://www.pis.org.pl/article.php?id=15817, 11.05.2010 r.

${ }^{34}$ Jarosław Kaczyński: „Landyzacja” Polski tylnymi drzwiami, „Gazeta Wyborcza Bydgoszcz", http://wiadomosci.gazeta.pl/kraj/1,34309,5246882.html, 17.10.2010 r. 
mogły działać jak etykietki (labeling) ${ }^{35}$ i „słowa - klucze”, które miały stygmatyzować, wywoływać w odbiorcy niechęć do „obiektu” wypowiedzi ${ }^{36}$.

Należy dodać, że w badanym okresie J. Kaczyński jednorazowo zadeklarował, że zarówno on, jak i posłowie PiS zmienią swój język. Deklaracja padła na II Kongresie Prawa i Sprawiedliwości ${ }^{37}$, w związku z nią prezes PiS stwierdził nawet: „Polityka pokoju, którą ogłosiłem na kongresie, wynika z mojej osobowości” (1.02.2009 r.) ${ }^{38}$. Niemniej słowa te nie potwierdziły się i nie miały kontynuacji. J. Kaczyński po ponad roku skonstatował: „Sytuacja się zmienia, ludzie się zmieniają, partia się zmienia więc i ja będę pewnie troszkę inny, ale jednak ten sam. Bo ludzie się zmieniają, ale jednak pozostają tacy sami. Czym człowiek ma więcej lat, tym trudniej jest mu się zmieniać, a ja już trochę mam" (7.03.2010 r.) ${ }^{39}$.

\section{WNIOSKI}

ZDANIEM J. BRALCZYKA, istnieją trzy wzorce komunikacji politycznej, które odzwierciedlają wybory ideologiczno-polityczne: konserwa-

35 Zob.: M. Głowiński, Pisomowa czyli o wolnoamerykance językowej, „Polityka. Niezbędnik inteligenta” 2006, nr 50, s. 14-18. Autor poruszył w tym tekście kwestię języka PiS, pisał m.in. o jednowartościowości tego języka, jego magii, charakterze oskarżycielskim, pasji demaskatorskiej, jak również o języku lustracji czy języku walki; zob. E. Pieciul-Karmińska, Językowe nadużycia. Stowa jak arszenik, „Polityka”, http:// www.polityka.pl/spoleczenstwo/niezbednikinteligenta/216106,1,jezykowe-naduzycia. read, 11.05.2010 r.

${ }^{36}$ Współcześnie etykietki są „zaledwie bronią w polemikach, ale upraszczając rzeczywistość i korzystając z atrakcyjnej formuły nacechowania i skrótu, nie są przecież bronią etycznie całkiem usprawiedliwioną. Produkują agresję zarówno, u tych, którzy je chętnie stosują, jak u tych, których określają".

${ }_{37}$ Zob. II Kongres Prawa i Sprawiedliwości w Krakowie (31.01.2009 r.), http://www.pis.org.pl/multi media.php?st=120\#, 11.05.2010 r.; II Kongres Prawa i Sprawiedliwości w Krakowie, http://www.pis.org.pl/ article.php?id=14332, 11.05.2010 r., a także wypowiedzi Jarosława Kaczyńskiego na temat Kongresu i „polityki miłości”: „Tomasz Lis na Żywo” TVP2, http://www.tvp.pl/publicystyka/polityka/tomasz-lis-na-zywo/wideo/ rozmowa-z-jaroslawem-kaczynskim-09022009/299577, 11.05.2010 r. oraz „Kropka nad i” TVN24, www.tvn24. pl/5249,kropka_nad_i.html, data odczytu: 11. 05. 2010 r..; zaś o zaprzeczeniu polityki miłości PiS, pisze T. Lis, http://www.tomaszlisnazywo.pl/lis_pisze/209,kompropis_felieton_w_gazecie_wyborczej_o6032009. html, 10.04.2011 r.

${ }^{38}$ Jarosław Kaczyński: kilkunastu europostów PiS byłoby sukcesem, http://www. pis.org.pl/ article.php?id=14350, 11.05.2010 r.

39 Jarosław Kaczyński dla PAP: będę troszkę inny, http://www.pis.org.pl/article. php?id=16927, 11.05.2010r. 
tywny, liberalny i socjalistyczny ${ }^{40}$. J. Kaczyński, wywodzący się z PiS i przewodzący temu prawicowemu ${ }^{41}$ ugrupowaniu, w badanym okresie mówił językiem konserwatywnym („Prawo i Sprawiedliwość jest partią nowoczesnego konserwatyzmu”)42. Język ten odsyłał do wartości narodowych, antykomunistycznych, tradycyjnych, katolickich, określanych jako patriotyczne i niepodległościowe ${ }^{43}$. Wśród jego wypowiedzi nie brakowało takich, w których utożsamiał się z „narodem polskim”, „Polską”, „Polakami”. W rezultacie prezes PiS chętnie wygłaszał przemówienia w imieniu innych, wypowiadając się w imieniu Narodu, Polski, jakiejś grupy ludzi (np. „PiS nie jest dla siebie, jest dla narodu") 44 .

W wypowiedziach z lat 2007-2010 J. Kaczyński, zgodnie z normą języka konserwatywnego, nie stronił od sugestii, że nazywa rzeczy po imieniu, mówi wprost, toteż często zmuszony jest zachowywać się konfrontacyjnie. Jego język był twardy, lider PiS sądy wypowiadał jakby tonem nieznoszącym sprzeciwu. Często zdarzało się, że przeciwnikowi odbierał prawo uczestnictwa w dialogu, np. z powodu jego niechlubnej (komunistycznej) przeszłości. Ton, jakim wypowiadał stwierdzenia, wskazywał, że pewien jest swych racji, co często skutkowało arbitralnymi opisami rzeczywistości i mieszaniem zasad ze stanem faktycznym ${ }^{45}$.

Należy też podkreślić, że nieraz w badanym okresie okazywało się, że wypowiedzi prezesa PiS obarczone są swoistą paradoksalnością albo lepiej - niedopasowaniem formy do treści. Potępiając PRL

${ }^{40}$ J. Bralczyk, O języku..., op. cit., s. 98-99.

${ }^{41}$ I. Kamińska-Szmaj, pisząc o „Gazecie Polskiej” w swojej książce „Słowa na wolności”, przywołuje zwrot „gniewny język prawicy” (za: D. Dabert, Gniewny język prawicy, „Odra” 1997, nr 10), który dobrze opisuje język stosowany przez J. Kaczyńskiego. Według autorki wyrasta on z poczucia zagrożenia i z chęci działania dla dobra ogółu. Zjawiska i osoby niebezpieczne, zagrażające wartościom tradycyjnie cenionym przez ugrupowania prawicowe, są nazywane wprost i dosadnie, co wzmaga emocjonalizację odbioru w wyniku nagromadzenia m.in. wyrazów ekspresywnych: „złodziejstwo”, „agenci”, „mafia”, „szajka”, „grupa”; kwantyfikatorów: „wszyscy”, „każdy”, „zawsze”, „,igdy”; orzeczeń modalnych: „trzeba”, „musimy”, „nie wolno”; oskarżeń wobec przeciwników poprzez stosowanie orzeczenia w 3 osobie liczby mnogiej: „zapomnieli”, „zrobili”, „omamili”.

${ }^{42}$ Wypowiedź z 8.10.2007 r., Premier do kobiet: jesteśmy partią nowoczesnego konserwatyzmu, http://www.pis.org.pl/article.php?id=10163, 11.05.2010 r.

${ }^{43} \mathrm{~J}$. Bralczyk, O języku..., op. cit., s. 99.

${ }^{44}$ Wypowiedź z 6.03.2010 r., Jarostaw Kaczyński na III Kongresie Prawa i Sprawiedliwości: chcę być premierem, by realizować program 202O, http://www.pis.org. $\mathrm{pl} /$ article.php?id=16912; 2.11.2010 r.

45 J. Bralczyk, Ojęzyku..., op. cit., s. 99. 
i wszelkie jego cechy charakterystyczne z nowomową, propagandą i jednowartościowością języka na czele, J. Kaczyński używał w swych wypowiedziach perswazyjności nieodległej od peerelowskiej. Pojawiały się w nich zatem wielosłowie i pustosłowie, obarczone brakiem jednoznaczności i abstrakcyjnością. Lider Prawa i Sprawiedliwości często stosował również wypowiedzi performatywne ${ }^{46}$, używając takich czasowników jak „wzywam”, „apeluję”, „ogłaszam”, które sygnalizują nie tylko chęć oddziałania na odbiorcę, lecz również poczucie sprawczości (np. „Apeluję o niełamanie prawa”)47.

Konserwatywny język J. Kaczyńskiego z lat 2007-2010 był również językiem wiodącego opozycjonisty, a także nosił cechy „języka opozycji”. W myśl stwierdzenia J. Bralczyka: „Wypowiedzi człowieka publicznego uniezależniają się od niego i tworzą jego obraz"48. Wypowiedzi J. Kaczyńskiego stworzyły obraz polityka inspirującego się w swych wystąpieniach przede wszystkim własną ideologią i wynikającym z niej programem politycznym. Zgodnie z nimi, za wszelką cenę należy walczyć o odcięcie Polski i Polaków od peerelowskiego balastu, który sprawia, że naród polski nie potrafi udźwignąć swej suwerenności, hołdując zanadto możnym sąsiadom. Niemniej ten radykalny osąd, wypowiadany wielokrotnie przez J. Kaczyńskiego, zyskiwał często przeciwwagę w postaci wypowiedzi, w których lider PiS chwalił demokrację, rządy prawa i reguły aktualnej gry politycznej w naszym kraju. W efekcie, mimo radykalizmu i skłonności do konfrontacyjnych osądów, J. Kaczyński operował zabiegami lingwistycznymi, które nie charakteryzują raczej ,języka opozycji antysystemowej”. Prezes Prawa i Sprawiedliwości kontestował wprawdzie wiele elementów polskiego ustroju, takich jak dominująca kultura polityczna czy wadliwie funkcjonujące i niewydolne instytucje państwowe. Niemniej nie podważał demokratycznego fundamentu III RP, a także nie kwestionował legalności rządów koalicji PO-PSL.

${ }^{46}$ Wypowiedzi performatywne - przyczynowe, spełniające; są wypowiedziami, które stwarzają realne skutki czyli rzeczywistość. W polityce są najczęściej apelem skierowanym do uczuć odbiorcy, podkreślają wspólnotę interesów, poprzez użycie pierwszej osoby liczby mnogiej: „sprzeciwiamy się”, „żądamy”, „nawołujemy do”.

${ }^{47}$ Wypowiedź z 10.10.2009 r., Prezes PiS: kolejna afera świadczy o kryzysie państwa, http://www.pis.org.pl/article.php?id=15998; 28.06.2010 r.

${ }^{48}$ J. Bralczyk, O języku..., op. cit., s. 260. 


\section{SUMmary}

THIS PAPER DISCUSSES Jarosław Kaczyński's public utterances from 2007 to 2010. It explains the typical features of a language, political language and the language of opposition. J. Kaczyński's political language was the language of a leading oppositionist. Populism, performative speech, thematic persistence, labeling, verbosity, prolixity, rhetorical tricks, neologisms, sense of efficacy, arbitrary description of reality are all the examples of his public utterances. The statesman denied many elements of Polish political system However, the democratic foundations of the III RP as well as the legitimacy of PO-PSL coalition were not questioned.

\section{NOTA O AUTORCE}

Agnieszka Jakubowska [agnieszka3e@wp.pl] - studentka I roku studiów II stopnia na kierunku politologia na Wydziale Nauk Politycznych i Dziennikarstwa UAM. Interesuje się środkami masowego przekazu, metodami i środkami wywierania wpływu społecznego oraz językiem polityki, w szczególności jego wpływem na zachowania wyborcze. 